\title{
Dusée, De Wind and Smellie: An Addendum.
}

\author{
By Alban Doran, F.R.C.S.
}

IN the article in the September number of the Journal, I referred to Dusée's pupil De Wind, whose name is sometimes spelt De Windt, giving a drawing of his forceps. I added that $I$ had failed to find his account of Dusée. I further observed (pp. 122, 142) that Smellie employed and rejected Dusée's forceps before contriving his own. Since the article in question appeared in print, I have received some valuable information from Professor Kouwer of Utrecht, throwing light on Dusée's relations to De Wind, which I publish below, adding some paragraphs, taken direct from Smellie's Treatise and Collection, on that great obstetrician's experience and rejection of Dusée's forceps.

Writing from Utrecht on September 24 1912,1 Professor B. J. Kouwer informs me that in the Mulder Collection attached to the University there is no sample of Dusée's forceps. Mulder, it will be remembered by those who have read my notes on that instrument, had never seen it, but took his account from Butter and De Wind's writings. Professor Kouwer has been good enough to translate all that is said about Dusée in De Wind's work, "'t Gelilemd Hoofd geredt" (The Arrested Head Saved). According to the title page of this work, published in 1751, Paulus De Windt (sic) was a lecturer on Anatomy, Surgery and Obstetrics, who practised as a lithotomist and obstetrician in Middelburg, province of Zealand in the United Netherlands.

\section{'Translation of De Wind's Oeservations about Dusée.}

(p. 2.) "In 1734 when in Paris, I desired, having completed my academical cducation, to gain some knowledge of midwifery and lithotomy. I therefore went to the renowned obstetrician Grégoire, the younger, and attended, with some other foreigners, his lectures, until he was prepared to show us his clinical work. Grégoire demonstrated to us, amongst other instruments, two large, long spoons which could be coupled by means of a transverse cross-hook. This instrument he called the tire-tête of Palfyn, and taught us that it was of use in extracting living children by the head without

I. Professor Kouwer sent me, with the above letter, a photograph of the forceps in the Mulder collection, which resembles Dusée's (see "Dusée: His Forceps, etc.," p. I22). The blades, not fenestrated, are similiar but there is only one lock and that is quite unlike Dusée's. 
injury. It seemed to me very serviceable and worthy of adoption, therefore I was surprised to witness M. Grégoire extracting children with the crotchet, and sacrificing the living child on more than one occasion, instead of employing this instrument which could save the child .. . I noticed that the tire-tete, which ho had demonstrated to us, was very rusty, from which I concluded that Grégoire himself did not make use of this instrument, though he recommended it to us, doubtless because his own experience of it had been unfavourable.

" Later on, I lived in the house of M. Dusse (sic), another wellknown obstetrician, who showed me and my fellow-traveller, Mr. J. Boswell, now a Doctor of Medicine in Edinburgh, another instrument for the same purpose, which he declared to us was his own invention. It was the forceps a sample of which was obtained from him by Mr. Alexander Butter ${ }^{1}$ and represented in the third volume of Wedical Essays of Edinburgh. I never saw him use it, for unfortunately soon after we took up our abode with him he fell ill and died. We saw him, however, deliver a few women. We bought the instrument from his heirs and it fell to the lot of Mr. Boswell, but I had another constructed immediately, and after returning to Zealand in the Netherlands I soon found by experience that it was unsuited for its purpose. It was far too large and I could not introduce it into the body of my patient."

(Here follow some pages relating De Wind's personal experiences with other forceps, and also with his own instrument described and figured in the article on Dusée in the Jovrsal of October 1912.)

(p. 30.) "It too often happens that teachers, after they have found that instruments which they have designed on theoretical principles are of no use in practice, cannot desist from demonstrating and expressing approval of them to their pupils... . Thus we see the useless instrument of Dussé described in full in the Scottish transactions above quoted, and that of Palfyn in Heister's cxcellent work. I think that a good book might be written on bad surgical instruments; it is with such contrivances as with bad books, men who have laid out money on them are not inclined to throw them away and people buy them so as to give themselves a name by saying that they possess them."

Smelute ANd Dusée,

Dusée's instrument was honoured by Smellie, as it was the first forceps that he made use of. The great obstetrician's experiences are to be found recorded in full in one of the New Sydenham's

I. Butter exhibited his sample of Dusée's forceps in 1733 , the year before Dusée's death, which, as De Wind testifies above, occurred when that pupil was living with him. 
Society's publications. It is sufficient for the present purpose to quote how Smellie set to work to test and to devise instruments for the saving of the child when the head was arrested in the pelvis. "In order to avoid this loss of children which gave me great uneasiness, I procured a pair of French forceps, according to a draught published in the Medical Essays by $\mathrm{Mr}$. Butter, but found them so long, and so ill-contrived that they by no means answered the purpose for which they were intended," 2 Thus Smellie began his experiences of the forceps by making use of Dusce's, the original description of which, by Butter, was given in full in the Journal, September 1912, p. 123 . In another part of his Treatise, namely in his chapter on fillets and forceps, Smellie writes: "A forceps was also contrived at Paris, a drawing of which may also be seen in the Medical essays of Edinburgh, in a paper communicated by $\mathrm{Mr}$. Butter, surgeon: but after Mr. Chapman had published a delineation of his instrument, which was that originally used by the Chamberlains (sic), the French adopted the same species, which among them went under the denomination of Chapman's forceps."3

Smellie's actual experience of Dusée's forceps is dated 1737, or four years after Butter had exhibited the instrument at Edinburgh. The fotal head was arrested in the pelvis. "I first tried to deliver the head with the French Forceps recommended by Mr. Butter in the Medical Essays of Edinburgh, but they were so long and illformed that I could not introduce them safely to take a proper hold." 3 Smellie was compelled to resort to craniotomy and evisceration.

Thus Dusée's forceps, of high interest in the history of the development of that instrument, was tried and found wanting not only by the great Smellie but also by the inventor's own pupil De Wind. The latter shows that Dusée died somewhat prematurely and implies that possibly he had never used his own forceps. Perhaps then, had he lived, he might have devised some at least of those improvements which his contemporaries, who outlived him, were able to make and to establish.

I. Treatise on the Theory and Praciice of Midwifery, edited, with illustrations, by Alfred $\mathrm{H}$. Mcclintock, 1876. A Collection of Cases and Observations in Midwifery, second edition, 1779 , vol. ii, p. $3 x$; and Treatise, McClintock's edition, vol. ii, p. 250. These quotations from Smellie are taken from three odd rolumes of his works in the library of the College of Surgeons.

2. Ibid, from thitd edition of Treatise, I779, vol.i, p.2I4. (The transition period, in regard to capital letters for common nouns, is shown in the above quotations as compared with extracts from Butter, Chapman and Giffard in the previous article.) See also Treatise, McClintock's edition, vol.i, p.25I.

3. A Collection of Pretematural Cases and Obstervations in Midwifery, I779, vol. iii, p. I2 (this volume was prepared after Smellie's death). Also Treatise, McClintock's edition, Case 28i, vol. ii, p. 375 . 
There remains a second great authority, a fellow countryman of Dusée, whose opinion of the forceps is worth recording, for, as will be seen, he associates the name of Dusée with the concave termination of the forceps, rather than with the two locks.

\section{Levret and Dusḱe.}

In "Dusée: His Forceps, etc.," mention was made of the fact that Levret spoke well of Palfyn and dwelt at length on the merits of his instrument. Levret ${ }^{\prime}$ further writes, most instructively, on improvements made by others, "perfections que les tenettes de Palfin (sic) ont acquises." He refers to novelties in the mechanism of the blades especially as to the lock or hinge. Palfyn's instrument had no lock, it was not even crossed. Levret writes about the different means by which other obstetricians endeavoured to make the blades act well together even if detachable. The claims of Le Doux and others caused confusion, as is to be found in Mulder's Historia Frorcipum, where there is a forceps incogniti which later on, in Kilian's Atlas, was ascribed to Palfyn. When Levret speaks of the methods already adopted, he shows how a hook joining the blades, and then, in preference, a big serew, the blades being crossed, proved alike unsatisfactory. Then two locks were devised, each to be used when required, but this forceps, Dusée's in fact, proved unsatisfactory, as Levret informs us:-

"Pour remédier done à l'inconvénient dont nous avons ci-devant parlé, on longea l'entablement, auquel on fit deux trous taraudés à quelque distance l'un de l'autre pour s'en servir ad libitum ce qui a rendu ce défaut moins grand; mais il a peu diminué le premier, qui étoit la difficulté de croiser ces piéces l'une sur l'autre et de les assujettir avec la Vis à tête aîlée dans le lieu qu'on avoit choisi; cela ne pouvoit pas se faire sans aide, ni sans beaucoup tâtonner dans celui-ci, non plus que dans celui à oeil simple ce qui allongeoit beaucoup les opérations." ${ }_{2}$

Thus we learn from the great Levret that Dusée's forceps with its two locks had been tried and found defective. Under the words "ad libitum" Levret adds a footnote: "On en voit une Figure à la planche 5 du troisième volume des Mémoires de la Société d' Edimbourg traduit en François." This "figure" represents Dusée's forceps and it was reproduced in the article on "Dusée: His Forceps," etc., Fig. 3.

For some reason not explained, Levret makes no mention of Dusée in the above criticism of his forceps. Yet further on, when

I. Observations sur les causes et les accidens de plusieurs accouchements laborieux, Paris, I747. The above quotations were taken from a copy belonging to the Library of the Royal College of Surgeons.

2. Loc. cit., p. 85 . 
he treats of the modifications of the ends of the blades, he states that after extreme breadth had been tried and proved objectionable, Dusée introduced the concave notch at the moderately broadened free end of each blade:-

"M. Dussé Chirurgien de Paris les fit échancrer en forme de croissant, dont les angles à la verité, étoient très-mousses, mais toujours trop saillans pour en permettre aisément l'introduction," etc. ${ }^{2}$

Thus, in 1747 at least, Levret recognized Dusée as the contriver of a forceps concave at its end, but did not seem aware that Dusée introduced the second lock, though he had apparently read Butter's paper. Levret never states that Dusée ever used his own forceps, yet he implies that others used it and found it unsatisfactory. The discrepancy about the second lock is not clear. Perhaps Levret happened to know that Dusée did not invent it, but for unknown reasons concealed the fact.

I. Sic. Modern French writers, Charpentier, Bat and others spell it "Dusée."

2. Loc. cit., p. 89 . 